Al-Madrasah: Jurnal Ilmiah Pendidikan Madrasah Ibtidaiyah

Vol. 4, No. 2, 2020

DOI 10.35931/am.v4i2.323

P-ISSN: 2620-5807; E-ISSN: 2620-7184

\title{
PENGARUH POLA ASUH KELUARGA TERHADAP PERILAKU PESERTA DIDIK DI MI MA'ARIF NU BRUNOSARI PURWOREJO JAWA TENGAH
}

\author{
Siti Anisatun Nafi'ah ${ }^{1}$, Ita Hesti Ernawati ${ }^{2}$ \\ Dosen Prodi PGMI STAINU Purworejo Jawa Tengah Indonesia ${ }^{1}$, Mahasiswa \\ Prodi PGMI STAINU Purworejo Jawa Tengah Indonesia ${ }^{2}$ \\ e-mail: anisnafiah14@gmail.com¹,dikalove649@gmail.com²
}

\begin{abstract}
Abstrak
Family care patterns have an important role in shaping children's behavior. Pla foster children from childhood describe the behavior of children when children are adults. Good parenting will produce good child behavior. In this study the authors found a student who has a different behavior with his friends. Therefore the author wants to examine the effect of family parenting on children's behavior.

This research uses qualitative research. Data analysis techniques used in this study with descriptive research, a researcher conducts the analysis only up to the description level, namely analyzing and presenting facts systematically so that it can be more easily understood and concluded.

Based on the results of the study the authors found that students are very difficult to regulate in the learning process in class. Students when learning only play and draw. The student is difficult to manage not only during class hours, at the time of the ceremony he also can not be silent. Based on the results of educator interviews with his family that the child is only raised by a grandmother. Parents of students have divorced.
\end{abstract}

Keywords: Parenting, Behavior, Students.

\begin{abstract}
Abstrak
Pola asuh keluarga memiliki peranan penting dalam pembentukan perilaku anak. Pla asuh anak sejak kecil menggabarkan perilaku anak ketika anak telah dewasa. Pola asuh yang baik akan menghasilkan perilaku anak yang baik. Pada penelitian ini penulis menemukan seorang peserta didik yang memiliki perilaku yang berbeda dengan temantemanya. Oleh sebab itu penulis ingin mengkaji tentang pengaruh pola asuh keluarga terhadap perilaku anak.
\end{abstract}


Penelitian ini menggunakan penelitian kualitatif. Teknik analisis data yang digunakan dalam penelitian ini dengan penelitian deskripsi, seorang peneliti melakukan analisis hanya sampai pada taraf deskripsi, yaitu menganalisis dan menyajikan fakta secara sistematik sehingga dapat lebih mudah untuk dipahami dan disimpulkan.

Berdasarkan hasil penelitian penulis menemukan bahwa peserta didik sangat sulit diatur dalam proses pembelajaran di kelas. Peserta didik ketika belajar hanya bermain dan menggambar. Peserta didik tersebut pun sulit diatur tidak hanya pada saat jam pelajaran saja, pada saat upacara dia juga tidak bisa diam. Berdasarkan hasil wawancara pendidik dengan keluarganya bahwa anak tersebut hanya diasuh oleh nenek. Orang tua dari peserta didik telah bercerai.

Kata kunci: Pola Asuh, Perilaku, Peserta Didik.

\section{PENDAHULUAN}

Menurut Abu Ahmadi secara sosiologi, keluarga adalah "Bentuk masyarakat terkecil yaitu kelompok sosial dimana anak-anak menjadi anggotanya dan keluarga menjadi tempat untuk bersosialisasi di kehidupan mereka. ${ }^{1}$ Keluarga sebagai kesatuan terkecil dalam masyarakat merupakan bagian dari pendidikan masyarakat. Keluarga dilihat dari segi sosial merupakan satu kesatuan hidup, dimana keluarga menyediakan anak dalam situasi pembelajaran. Keluarga sebagai sistem sosial teridiri dari ayah, ibu, dan anak sehingga dapat membantu ikatan kekeluargaan seperti mengembangkan sifat persahabatan, cinta kasih, hubungan antar pribadi, kerjasama, disiplin, tingkah laku yang baik.

Orang tua memiliki peran penting dalam menciptakan lingkungan sosial yang kondusif karena orang tua memiliki tanggung jawab untuk mengasuh dan mendidik anak. Dimana dalam mengasuh orang tua menggunakan pola interaksi antara anak dan orang tua dalam proses pengasuhan, artinya dalam proses pengasuhan orangtua memiliki kontribusi yang signifikan dalam pembentukan kepribadian anak yang sesuai dengan norma masyarakat yang berlaku. Orang tua dalam mengasuh anaknya memiliki ciri khas tersendiri yang mana penggunaan pola asuh ini akan memberikan sumbangan dan warna terhadap bentuk-bentuk perilaku sosial tertentu pada anaknya. ${ }^{2}$

Orang tua dan pola asuh merupakan dua hal yang tidak dapat

1 Nursyamsiyah Yusuf, Ilmu Pendidikan, (Tulungagung: Penerbitan dan Publikasi Sekolah Tinggi Agama Islam Negeri Tulungagung, 2000), hlm. 65.

2 Harbeng Masni, Peran Pola Asuh Demokratis Orangtua Terhadap Pengembangan Potensi Diri Dan Kreativitas Siswa, Jurnal Ilmiah Universitas Batanghari Jambi Vol.17No.1 Tahun 2017, hlm. 69.

Al-Madrasah: Jurnal Ilmiah Pendidikan Madrasah Ibtidaiyah Vol. 4, No. 2, Januari-Juni 2020 
dipisahkan karena memiliki kontribusi dalam menanamkan dasar kepribadian akan yang nantinya akan menentukan corak dan gambaran anak kelak ketika dewasa. Setiap orang tua memiliki metode dan pola asuh tersendiri dalam mengasuh anak yang nantinya metode dan pola tersebut akan berbeda antara satu keluarga dengan keluarga lainnya. Pola asuh orang tua adalah deskripsi tentang tingkah laku orang tua dan anak ketika berinteraksi, dan berkomunikasi selama melakukan kegiatan pengasuhan.

Ada beberapa pendekatan yang digunakan oleh orang tua untuk pengasuhan antara lain pendekatan otoriter, permisive, dan demokratis. Pola asuh demokratis yaitu pola asuh yang dicirikan oleh komunikasi terbuka. Berbeda dengan pola asuh otoriter yang lebih menegaskan adanya aturanaturan orangtua yang otoriter dan komunikasi cenderung melalui perintah kepada anak. Komunikasi yang hanya satu arah ini mengakibatkan anak tidak memiliki kesempatan untuk mengemukakan pendapat. Orang tua yang otoriter bertumpy pada hukuman yang pada akhirnya menyakitkan, aturan yang tidak dapat diubah dan tidak memerlukan pendapat anak untuk mengambil keputusan.

Sedangkan pola asuh permisif adalah pola asuh orang tua yang serba membolehkan kepada anak seperti membiarkan anak melaksanakan keinginannya dan memanjakan anak sehingga dapat mengabaikan anak. Pola asuh demokratis adalah pola asuh orang tua yang dapat menciptakan komunikasi yang interaktif seperti menghargai pendapat anak, norma dalam keluarga dibuat berdasarkan kesepakatan bersama dan memberikan bimbingan yang positif.

Berdasarkan uraian di atas dapat dipahami bahwa pola asuh orang tua berperan penting terhadap perilaku anak di sekolah. Pola asuh yang demokratis akan menumbuhkan rasa tanggung jawab atas pilihan anak, pola asuh otoriter akan membuat anak menjadi tidak kreatif dan pola asuh permisif akan membuat anak bebas bertindak sewenang-wenang. Pentingnya pengaruh dari pola asuh orang tua terhadap perkembangan perilaku anak mendorong penulis untuk mengkaji aspek ini secara mendalam bagaimana pengaruh pola asuh keluarga terhadap perilaku peserta didik di MI Maarif NU Brunosari.

\section{METODE PENELITIAN}

Penelitian yang digunakan dalam penelitian ini merupakan penelitian kualitatif. Penelitian kualitatif adalah suatu penelitian yang bertujuan untuk menggambarkan dan menganalisis fenomena, peristiwa, aktivitas sosial, sikap, kepercayaan, persepsi, pemikiran orang secara 
individual maupun kelompok. ${ }^{3}$

Lokasi penelitian adalah MI NU Maarif Brunosari. MI NU Maarif Brunosari terletak di dukuh sabrang wetan brunosari Kec. Bruno, Kab. Purworejo, Jawa Tengah. MI NU Maarif Brunosari berdiri pada tahun 2011. Jumlah siswa yaitu 206 sedangkan guru dan karyawan berjumlah 23 orang.

Teknik pengumpulan data yang digunakan dalam penelitian yaitu teknik wawancara dan observasi. Sumber Wawancara adalah guru kelas, nenek, dan orang terdekat dengan informan. Adapun observasi dilakukan di MI NU Ma'arif Brunosari.

Teknik analisis data yang dilakukan dalam penelitian ini adalah penelitian deskripsi. Dalam penelitian deskripsi peneliti melaksanakan analisis hanya sampai pada tingkatan deskripsi yakni menganalisis dan menyajikan fakta secara sistematik sehingga pembaca dapat memahami dan menimpulkan. Kesimpulan yang ditujukan selalu jelas dasar faktualnya, sehingga semuanya selalu dapat dikembalikan langsung berdasarkan data yang diperoleh.

\section{KAJIAN TEORI}

\section{Pola Asuh Orang Tua}

Pola asuh memiliki dua kata yaitu pola dan asuh. Menurut KBBI pola memiliki arti sistem, cara kerja, bentuk (struktur) yang tetap. Asuh memiliki makna jaga, bimbing, pimpin. ${ }^{4}$ Berdasarkan definisi di atas maka dapat disimpulkan bahwa pola asuh merupakan cara kerja untuk membimbing.

Menurut pandangan ahli psikologi dan sosiologi memiliki pengertin yang berbeda. Singgih D Gunarso berpandangan bahwa pola asuh adalah deskripsi yang dipakai oleh orang tua untuk mengasuh (merawat, menjaga, mendidik) anak. Berbeda dengan Chabib Toha yang menyatakan bahwa pola asuh adalah suatu metode terbaik yang dapat dilakukan oleh orang tua untuk mendidik anak sebagai bentuk dan rasa tanggung jawab kepada anak. ${ }^{5}$

Menurut Petranto pola asuh orang tua adalah gambaran perilaku yang diberikan kepada anak yang sifatnya relative konsisten dari waktu ke waktu. Gambaran perilaku dari orang tua dapat dirasakan anak baik positif ataupun negative. Setiap keluarga menanamkan pola asuh yang berbeda, karena pandangan orang tua

3 Nana Syaodih Sukmadinata, Metode Penelitian Pendidikan, (Bandung: Rosdakarya, 2012), hlm. 60.

${ }^{4}$ https://kbbi.kemdikbud.go.id/ diakses pada tanggal 27 Januari 2020.

${ }^{5}$ Al Tridhonanto dan Beranda Agency, Mengembangankan Pola Asuh Demokratis, (Jakarta: PT Elex Media Komputindo, 2014), hlm. 4. 
berbeda. Gunarsa berpendapat bahwa pola asuh adalah metode orang tua bertindak sebagai orangtua kepada anak-anaknya dengan serangkaian usaha yang aktif. ${ }^{6}$

Dari beberapa definisi di atas dapat ditarik kesimpulan bahwa pola asuh adalah metode terbaik yang dilakukan oleh orang tua untuk mengasuh dengan serangkaian usaha aktif yang bersifat relatif konsisten dari waktu ke waktu. Berdasarkan definisi di atas dapat dijabarkan bahwa orang tua mempunyai metode yang paling baik dalam merawat, menjaga, mendidik dengan usaha yang penuh giat. Orang tua dalam mengasuh anak memiliki ciri khas yang tetap dari waktu ke waktu.

Menurut Stewart dan Koch pola asuh orang tua mempunyai tiga kecondongan yaitu pola asuh otoriter, pola asuh demokratis, dan pola asuh permisif. Pola asuh otoriter adalah pola asuh orang tua yang lebih mengkhususkan dalam membentuk kepribadian anak melalui standar mutlak yang harus dituruti, dan biasanya beriringan dengan ancaman-ancaman. Pola asuh otoriter mempunyai ciri-ciri antara lain: (1) kehendak orang tua harus dipatuhi oleh anak; (2) perilaku anak dikontorol oleh orang tua sangat ketat; (3) pujian hampir tidak pernah diberikan kepada anak; (4) sifat komunikasi biasanya satu arah dan kompromi tidak dikenal oleh orang tua. ${ }^{7}$

Baumrind juga berpendapat bahwa pola asuh otoritatif atau demokrasi adalah pola asuh yang menekankan agar anak mandiri tetapi orang tua masih memberikan ketentuan-ketentuan dan pengendalian atas perilaku mereka. Kehangatan dan kasih sayang yang diberikan oleh orang tua dapat terjadi melalui musyawarah verbal. Pola asuh orang tua yang demokratis mengakibatkan anakanak mempunyai kepercayaan diri dan harga diri yang tinggi serta menunjukkan perilaku yang terpuji. ${ }^{8}$

Shapiro berpendapat pola asuh orang tua yang otoritatif yaitu ketika anak belajar maka orang tua akan menghargai kemandirian anak, memberikan dorongan dan pujian.

${ }^{6}$ Rabiatul Adawiah, Pola Asuh Orang Tua Dan Implikasinyaterhadap Pendidikan Anak (Studi pada Masyarakat Dayak di Kecamatan Halong Kabupaten Balangan), Jurnal Pendidikan Kewarganegaraan: Volume 7, Nomor 1, Mei 2017, hlm. 34.

7 Al Tridhonanto dan Beranda Agency, mengembangankan Pola Asuh..., hlm. 12.

${ }^{8}$ Husnatul Jannah, Bentuk Pola Asuh Orang Tua Dalam Menanamkan Perilaku Moral Pada Anak Usia Di Kecamatan Ampek Angkek, Jurnal Pesona PIAUD Vol 1., No. 1, hlm. 4. 
Berdasarkan pendapat para ahli diatas dapat disimpulkan bahwa penerapan pola asuh autoritatif mencirikan dengan penanaman nilai-nilai demokrasi yaitu menghargai dan menghormati hakhak anak, mengutamakan diskusi daripada perintah, kebebasan mengemukakan pendapat dan selalu memotivasi anak untuk menjadi yang lebih baik.

Pola asuh permisif biasanya menyerahkan pengawasan yang tidak ketat. Anak diberikan kesempatan untuk melaksanakan sesuatu tanpa pengawasan yang baik dari orang tua. orang tua bercondong untuk tidak mengangatkan anak ketika sedang dalam bahaya atau melakukan kesalahan, dan sangat sedikit pengarahan yang diberikan oleh orang tua. Tetapi tipe orang tipe ini kadangkala bersifat hangat sehingga disukai oleh anak. ${ }^{9}$

\section{Perilaku Peserta Didik}

Masalah yang penting yang harus diperhatikan oleh pendidik adalah gangguan perkembangan dan perilaku anak sekolah yang sangat variatif. apabila ganguan perkembangan dan perilaku anak tidak diketahui dan ditangani sejak dini, maka gangguan perkembangan dan perilaku anak ini akan berpengaruh pada prestasi belajar dan masa depan anak.

Perilaku dalam KBBI memiliki arti tanggapan atau reaksi individu terhadap rangsangan atau lingkungan. ${ }^{10}$ Dari pengertian di atas bahwa rekasi individu terhadap lingkungan memiliki rekasi yang berbeda-beda. Perilaku manusia terdiri dari dua hal yaitu nampak dan tidak nampak. Perilaku yang Nampak meliputi aktivitas motorik, kognitif maupun emosional. ${ }^{11}$

Gerungan berpandangan bahwa perilaku adalah keyakinan kepada objek tertentu, yaitu dapat berbentuk sikap pandangan atau sikap perasaaan. Tetapi perilaku yang disertai dengan keinginan untuk bertindak sesuai dengan sikap terhadap objek. ${ }^{12}$

Hal ini tidak berbeda dengan pendapat Arifin yang menyatakan bahwa sikap adalah suatu keinginan yang ditujukan seseorang untuk berperilaku yang disesuaikan dengan objek tertentu

${ }^{9}$ Dian Novita dan Muman Hendra Budiman, Pengaruh Pola Pengasuhan Orang Tua Dan Proses Pembelajaran Di Sekolah Terhadap Tingkat Kreativitas Anak Prasekolah (4-5 Tahun), Jurnal Pendidikan, Volume 16, Nomor 2, September 2015, hlm. 103.

${ }^{10} \mathrm{https}$ ://kbbi.kemdikbud.go.id/ diakses pada tanggal 27 Januari 2020.

11 Syamsul Bachri Thalib, Psikologi Pendidikan Berbasis Analisis Empiris Aplikati, (Jakarta: Kencana, 2010), hlm 184.

12 WA. Gerungan, Psikologi Sosial, (Bandung: Eresco, 1991), hlm. 149. 
melalui orang lain atau dirinya sendiri. ${ }^{13}$ Perilaku merupakan perwujudan dari respon atau reaksi seseorang terhadap rangsangan lingkungan sosial tertentu. Perilaku tergolong dalam ranah psikomotorik. Menurut Noer dan Muhadjir perilaku tidak hanya psikomotorik namun merupakan performance kecakapan. ${ }^{14}$

Perilaku secara umum dipengaruhi dan dikendalikan oleh dua faktor yaitu peristiwa yang sebelum suatu reaksi dan peristiwa yang menyusul kemudian. Hal yang terpenting adalah kita tidak dapat mengubah perilaku secara umum, tetapi kita dapat mengendalikan sebelum maupun sesudah perilaku terjadi. Kebanyakan perilaku (baik maupun buruk) yang terlihat di dalam diri anak-anak terutama mereka yang berumur di bawah 10 tahun, dapat dikatakan sebagai akibat pengaruh lingkungan. Tanpa mengubah lingkungan, suit mengubah perilaku siswa dimodifikasi, perubahan perilaku mudah dicapai. ${ }^{15}$

Ada beberapa faktor yang berpengaruh terhadap perilaku seseorang yaitu faktor internal dan eksternal. Faktor internal merupakan pengaruh emosi (perasaan), emosi mempunyai fungsi yang cukup besar dalam membentuk perilaku keagamaan. Menurut Zakiyah Darajat bahwa "sesungguhnya emosi menguasai peranan penting dalam tingkah laku dan tindak agama yang dipahami oleh seseorang. Lebih dijelaskan lagi bahwa pengaruh emosi lebih besar dibandingkan dengan logika walaupun seseorang tanpa menghindari. ${ }^{16}$

Faktor eksternal yaitu lingkungan keluarga dan masyarakat. Bagi anak pendidikan utama dan pertama adalah lingkungan keluarga. Keadaan pendidikan dapat diciptakan dalam keluarga apabila terdapat pergaulan dan interaksi yang saling memengaruhi melalui timbal balik antara orang tua dan anak. Keserasian keluarga dapat tercipta jika keadaan keluarga terbiasa melakukan perbuatan terpuji dan meninginggalkan perbuatan tercela. Maka pengaruh keluarga sangat mempengaruh pembentukan kepribadian anak.

${ }^{13}$ Ahmad Amin, Etika, Terj. Ahmad Ma'aruf, (Jakarta: Bulan Bintang, 1983), hlm. 12.

14 Lukman Hakim, Internalisasi Nilai-nilai Agama Islam dalam Pembentukan Sikap dan Perilaku Siswa Sekolah Dasar Islam Terpadu AlMuttaqin Kota Taksimalaya,Jurnal Pendidikan Agama Islam Ta'alim, Vol. 1. No. 1, 2012 , hlm. 70.

${ }^{15}$ Collins dan Mallary M, Mengubah Perilaku Siswa, Terj. Kathleen Sri Wardhani, (Jakarta: Gunung Mulia, 1992) ,hlm. 8-9.

${ }^{16}$ Zakiyah Darajat, Ilmu Jiwa Agama, (Bulan Bintang: Jakarta, 1970), hlm. 77-80

Al-Madrasah: Jurnal Ilmiah Pendidikan Madrasah Ibtidaiyah Vol. 4, No. 2, Januari-Juni 2020 
Siti Anisatun Nafi'ah, Ita Hesti Ernawati: Pengaruh Pola Asuh Keluarga Terhadap Perilaku Peserta Didik Di MI Ma'arif Brunosari Purworejo Jawa Tengah

\section{HASIL DAN PEMBAHASAN}

Penulis melaksanakan observasi di Marif NU Brunosari. Berdasarkan hasil observasi di Marif NU Brunosari terdapat seorang anak yang peserta didik tersebut mengalami keterlambatan dalam belajar dibandingkan dengan peserta didik di kelasnya. Ketika proses pembelajaran peserta didik tersebut tidak mau menulis atau melakukan kegiatan belajar lain. Hal ini berbeda ketika mata pelajaran seni budaya dan keterampilan, peserta didik tersebut bersedia menggambar.

Pendidik sampai hilang akal untuk mengatasi permasalahan pada peserta didik tersebut. Pendidik telah membujuknya agar dia bersedia menulis, akan tetapi semakin dibujuk dia malah menangis. Kadang di saat guru sudah tidak bisa membujuk maka di diamkan saja, yang penting tidak mengganggu teman yang lain pada saat proses pembelajaran. Pendidik terkadang mencoba membujuknya untuk menulis, namun peserta didik tersebut memiliki alasan bahwa tidak membawa pensil di sekolah.

Peserta didik tersebut cukup rajin berangkat sekolah. Setiap pagi dia berangkat, meskipun di sekolah hanya duduk kadang tidur sambil isep jempol. Dia juga sudah memahami waktu seperti waktunya istirahat dia bangun, waktunya pulang dia pulang, tetapi ketika waktu belajar yang masih sulit untuk dikendalikan oleh guru. Terkadang dia akan pulang dari sekolah lebih awal jika dia diusili oleh teman-temannya. Pendidik sudah mencoba membujuk agar tidak pulang ke rumah tetapi dia tidak dapat dicegah dan bersiap-siap untuk pulang ke rumah. Pada suatu ketika pendidik pernah mengerjar peserta didik tersebut tetapi dia tetap ingin pulang ke rumahnya.

Peserta didik tersebut pun sulit diatur tidak hanya pada saat jam pelajaran saja, pada saat upacara dia juga tidak bisa diam. Pendidik pun memiliki strategi agar dia di tempatkan di barisan paling belakang sehingga bisa diawasi oleh pendidik. Saat dia ngambek ketika akan upacara maka dia akan keluar dari barisan. Dia duduk di bawah pohon kemudian melempari batu ke teman temannya. Saat dia tidak mau ikut upacara, dia akan masuk di dalam kelas, gaduh bermain kursi dan meja.

Dewan pendidik akhirnya bermusyawarah bagaimana baiknya menyikapi peserta didik tersebut. Hasil keputusan dewan pendidik akhirnya memutuskan untuk pergi ke rumahnya tesebut. Hal ini dilakukan untuk mencari penyebab permasalahan apa yang sebenarnya dialami oleh peserta didik karena berbeda dengan peserta didik yang lain. Beberapa pendidik datang ke rumahnya dan bertemu dengan neneknya. Maksud dan tujuan pendidik hendak menyampaikan bagaimana baiknya mengatasi anak tersebut karena dia sering pulang tanpa izin dan tidak bisa di larang atau di bujuk, apakah sebaiknya biarkan saja dulu dirumah atau tetap sekolah. Neneknya hanya mengatakan supaya tetap sekolah saja, jika suatu saat dia bolos biarkan saja, tidak apa- apa. Memang anaknya seperti itu dan tidak akan menyalahkan pihak sekolah. 
Biarkan tetap sekolah semaunya kalau di rumah takutnya anaknya semakin nakal dan malas sekolah lagi.

Pendidik juga mencari informasi ke tetangga sekitar dan teman- teman TK, memang anaknya seperti itu, seperti punya kekurangan. Hal ini dikarenakan ayah ibunya bercerai saat dia bayi, sang ibu meninggalkan dia di tempat ayahnya, sang ayah harus bekerja untuk menafkahi dia sehingga dia ditinggal bersama neneknya. Sang ibu tidak ada kabar, menengok pun tidak pernah, bahkan di KK dan akte kelahiran tidak tertera nama ibunya. Tidak heran jika dia seperti itu, kurangnya kasih sayang orang tua itu membuat mentalnya terganggu, apalagi hanya tinggal bersama nenek dimana pola asuh nenek itu kadang bertolak belakang dengan pola asuh orang tua.

Akhirnya dari pihak sekolah dapat memahami dalam menangani dia. Metode yang dilakukan oleh pendidik adalah tarik ulur, dan membiarkan semau dia tapi tetap dalam pemantauan. Saat dia tidak mau menulis, maka pendidik memberikan peringatan agar tidak mengganggu temannya. Pendidik meminta peserta didik tersebut untuk menggambar saja. Jika dia sudah lelah dia akan tertidur atau main di kolong meja. Jika dia mau pulang, juga sudah tidak dilarang tapi ada guru yang mengikuti dia sampai rumah untuk memastikan anak sampai rumah. Tidak jarang sang nenek akan datang untuk mencari sepatunya yang tertinggal di sekolah

Berasumsi dari hasil analisis wawancara dan observasi dapat disimpulkan bahwa kurangnya kasih sayang dan pola asuh orang tua, terutama ibu sangat memengaruhi mental dan emosi seseorang. Meskipun sang anak tidak pernah bertanya ataupun memberontak namun sangat berpengaruh dalam pola pikir dan tingkah laku mereka. Dengan mereka bertindak yang tidak sewajar usia mereka sebenarnya itu cara mereka memberontak dan mencari perhatian. Kehangatan dalam keluarga diperlukan dalam proses tumbuh kembangnya anak. Mereka akan belajar dari orang tua dan lingkungan sekitar. Anak yang tumbuh di lingkungan keluarga yang harmonis dan tidak harmonis itu sangat berpengaruh pada keadaan psikologi anak. Secara kasat mata mereka akan tampak seperti anak- anak lain pada umumnya, namun secara kejiwaan anak yang tumbuh dari lingkungan keluarga yang tidak harmonis akan menunjukkan sifat- sifat tertentu.

Selain itu, anak yang tinggal atau di asuh nenek juga akan berbeda dengan yang diasuh orang tua. Karena kecenderungan sifat nenek dengan memakai metode yang penting anak diam, yang penting anak tidak rewel dan yang penting lainnya sehingga apa yang diminta sang anak selalu dituruti, itu akan mengakibatkan sifat dan efek yang tidak baik bagi perkembangan anak. Akhirnya anak akan manja dan tidak memahami peraturan. Berbeda dengan pola asuh orang tua, orang tua akan memberikan apa yang diminta sang anak sesuai kebutuhan sang anak, bukan sesuai permintaan sang anak. 
Siti Anisatun Nafi'ah, Ita Hesti Ernawati: Pengaruh Pola Asuh Keluarga Terhadap Perilaku Peserta Didik Di MI Ma'arif Brunosari Purworejo Jawa Tengah

\section{KESIMPULAN}

Pola asuh keluarga sangat mempengaruhi perilaku peserta didik ketika di sekolah. Peserta didik tersebut mengalami keterlambatan dalam belajar dibandingkan dengan peserta didik di kelasnya. Ketika proses pembelajaran peserta didik tersebut tidak mau menulis atau melakukan kegiatan belajar lain. Hal ini berbeda ketika mata pelajaran seni budaya dan keterampilan, peserta didik tersebut bersedia menggambar. Pendidik telah membujuknya agar dia bersedia menulis, akan tetapi semakin dibujuk dia malah menangis. Kadang di saat guru sudah tidak bisa membujuk maka di diamkan saja, yang penting tidak mengganggu teman yang lain pada saat proses pembelajaran.

Peserta didik tersebut pun sulit diatur tidak hanya pada saat jam pelajaran saja, pada saat upacara dia juga tidak bisa diam. Pendidik pun memiliki strategi agar dia di tempatkan di barisan paling belakang sehingga bisa diawasi oleh pendidik. Dewan pendidik akhirnya bermusyawarah bagaimana baiknya menyikapi peserta didik tersebut. Hasil keputusan dewan pendidik akhirnya memutuskan untuk pergi ke rumahnya tesebut. Anak tersebut ternyata hanya diasuh oleh nenek, dan orang tua telah bercerai. Maka dalam menangani perilaku anak dengan kasus di atas perlu kerjasama antara ayah, nenek, dan guru sehingga perilaku anak tersebut dapat diatasi dengan baik.

\section{DAFTAR PUSTAKA}

Adawiah, Rabiatul, Pola Asuh Orang Tua Dan Implikasinya terhadap Pendidikan Anak (Studi pada Masyarakat Dayak di Kecamatan Halong Kabupaten Balangan), Jurnal Pendidikan Kewarganegaraan: Volume 7, Nomor 1, Mei 2017.

Amin, Ahmad, Etika, Terj. Ahmad Ma'aruf, Jakarta: Bulan Bintang, 1983.

Arifin, Psikologi Dakwah, Jakarta: Bulan Bintang, 1997.

Bachri Thalib, Syamsul, Psikologi Pendidikan Berbasis Analisis Empiris Aplikati, Jakarta: Kencana, 2010.

Collins dan Mallary M, Mengubah Perilaku Siswa, Terj. Kathleen Sri Wardhani, Jakarta: Gunung Mulia, 1992.

Darajat, Zakiyah, Ilmu Jiwa Agama, Bulan Bintang; Jakarta, 1970

Gerungan, WA, Psikologi Sosial, Bandung: Eresco, 1991.

Hakim, Lukman, Internalisasi Nilai-nilai Agama Islam dalam Pembentukan Sikap dan Perilaku Siswa Sekolah Dasar Islam

Terpadu Al-Muttaqin Kota Taksimalaya, Jurnal Pendidikan Agama Islam Ta'alim, Vol. 1. No. 1, 2012.

https://kbbi.kemdikbud.go.id/ diakses pada tanggal 27 Januari 2020. 
Jannah, Husnatul, Bentuk Pola Asuh Orang Tua Dalam Menanamkan Perilaku Moral Pada Anak Usia Di Kecamatan Ampek Angkek, Jurnal Pesona PIAUD Vol 1., No. 1.

Masni, Harbeng, Peran Pola Asuh Demokratis Orangtua Terhadap Pengembangan Potensi Diri Dan Kreativitas Siswa, Jurnal Ilmiah Universitas Batanghari Jambi Vol.17 No.1 Tahun 2017.

Novita, Dian, dan Muman Hendra Budiman, Pengaruh Pola Pengasuhan Orang Tua Dan Proses Pembelajaran Di Sekolah Terhadap Tingkat Kreativitas Anak Prasekolah (4-5 Tahun), Jurnal Pendidikan, Volume 16, Nomor 2, September 2015.

Syaodih Sukmadinata, Nana, Metode Penelitian Pendidikan, Bandung: Rosdakarya, 2012.

Tridhonanto, Al dan Beranda Agency, Mengembangankan Pola Asuh Demokratis, Jakarta: PT Elex Media Komputindo, 2014.

Yusuf, Nursyamsiyah, Ilmu Pendidikan, Tulungagung: Penerbitan dan Publikasi Sekolah Tinggi Agama Islam Negeri Tulungagung, 2000. 
Siti Anisatun Nafi'ah, Ita Hesti Ernawati: Pengaruh Pola Asuh Keluarga Terhadap Perilaku Peserta Didik Di MI Ma'arif Brunosari Purworejo Jawa Tengah

Al-Madrasah: Jurnal Ilmiah Pendidikan Madrasah Ibtidaiyah Vol. 4, No. 2, Januari-Juni 2020 